\title{
Investigation of the relationship between pre-service science teachers' perceived self-efficacy in science teaching and disposition toward reflective thinking
}

\author{
Uluçınar Sağır, Şafak ${ }^{1}$, Aslan, Oktay², Bertiz, Harun ${ }^{3}$ and Öner Armağan, Fulya ${ }^{4}$ \\ ${ }^{1}$ Elementary Science Education Department, Amasya University, Amasya, Turkey \\ 2. Elementary Science Education Department, Necmettin Erbakan University, Konya,Turkey \\ ${ }^{3}$ Elementary Science Education Department, Abant İzzet Baysal University, Bolu,Turkey \\ ${ }^{4}$ Elementary Science Education Department, Erciyes University, Kayseri, Turkey \\ For correspondence: onerf@erciyes.edu.tr
}

\begin{abstract}
The study aims to examine the relationship between perceived self-efficacy in science teaching and disposition towards reflective thinking in pre-service science teachers based on different variables. For this purpose, the Perceived Selfefficacy Scale for Science Teaching and Disposition Towards Reflective Thinking Scale were conducted in 619 preservice science teachers attending four public universities in Turkey. The research results suggest a positive significant relationship between perceived self-efficacy in science teaching and disposition towards reflective thinking at mediumlevel. While perceived self-efficacy in science teaching did not have any significant difference in respect to gender, grade level, type of education, status of giving private lessons or type of high school, the difference based on the universities and sense of academic success of pre-service science teachers was found to be significant. Disposition towards reflective thinking is not significantly different based on grade, type of education, type of high school or status of giving private lesson, whereas significant differences are observed in respect to gender, universities and sense of academic success. A regression equation was devised for the variables that predict disposition towards reflective thinking. The implications were discussed.
\end{abstract}

Keywords: Self-efficacy, reflective thinking, science teaching, pre-service science teachers

\section{Introduction}

Today, students assume an active role in the very center of the questioning process so as to seek a solution to events and existing problems in school and learning life. Existing teaching programs which focus on the constructivist learning theory support this situation and process in terms of content. According to constructivist learning, students restructure information by using their previous knowledge and experience in the process of research and questioning. In this process, the teacher is expected to assume an active role by focusing students on the subject and problem and causing them to construct information through critical questions that stimulate deep thinking dynamically rather than merely being a passive guide asking short-answer questions. This evolution of understanding in education and the need for meaningful learning result in teachers and students acquiring the skills that are among the main components of education to be questioned. Students who construct information should be aware of their own responsibilities in such an active learning environment. They should be able to determine their own learning speed and needs, and should be able to make progress by identifying what is required to generate a resolution to a problem. A similar development and internal questioning mechanism should also apply to teachers and pre-service teachers in the context of qualifications and setting learning-teaching needs. 


\section{Reflective Thinking}

Reflective thinking, which has been frequently mentioned in education in recent years, is capable of improving several basic skills and needs that should be possessed by students and teachers as well as making several contributions to the educational environment. Ünver (2003) mentions that an education system that embodies reflective thinking gives students the opportunity to set their own learning goals and responsibilities, to correct their own mistakes and to express their opinions freely through self-stimulation thanks to being able to recognize their positive behaviors. On the other hand several institutions and agencies in the USA such as the National Board for Professional Teaching Standards (NBPTS), the National Commission on Teaching \& America's Future (NCTAF), the National Foundation for the Improvement of Education (NFIE) and the National Skills Development Center (NSDC), as well as governments and local school administrations perceive reflective thinking as a standard that should be required of all teachers and students (Tok, 2008). Therefore, a large number of countries are presently triying to develop and improve their educational standards. To this end, they include different projects and programs with a potential to influence. Tok (2008) points out that reflective thinking has been determined as one of the general qualification areas for teachers in the scope of the Support to Basic Education Project and that it is important to develop knowledge and attitude towards reflective thinking in teacher training programs so as to ensure that teachers acquire this skill. Also, he is of the opinion that reflective thinking could have a determining role in teacher education

Reflective thinking is a kind of thinking skill for individuals. It has been stated that developing this skill is not generally an easy task for individuals (Kuit, Reay \& Freeman, 2001; Lin, Hmelo, Kinzer \& Secules, 1999). In conceptual terms, reflection can be identified as the skill to assume responsibility in the realistic preferences and choices of an individual in terms of thinking; it is also an active, purposeful and stable thinking process used while attempting to generate practical solutions to problems (Ross, 1990; cited in Gözütok, 2006; Yorulmaz, 2006). An individual who thinks reflectively takes decisions for the solution of problems and realizes this decision, evaluating the results thereof (Norton, 1994).

According to Kızılkaya and Aşkar (2009), reflective thinking has aspects such as questioning, causation and evaluating, while Loughran (1996) mentions that reflective thinking includes phases such as claim, problem, hypothesis, judgment and testing. From a basic perspective, Dewey (1993) defines reflective thinking as effective, consistent and careful thinking about thought or information. In other words, reflective thinking is actively, continuously and carefully thinking on a subject.

Self efficacy is the judgment of an individual on their own capability to organize events and success in delivering a certain performance. Perceived self-efficacy is addressed at two levels, namely, selfefficacy expectation and result expectation; the former being about the individuals sufficiency to fulfil a work or task while the latter comprises an individual's beliefs on certain results that should arise from actions (Akbulut, 2006). Personal efficacy depends on 4 characteristics as suggested by social learning theory. These are performance skill, indirect experience (learning through modeling or observation), verbal persuasion and psychological state (Bandura, 1997). Therefore, the perceived selfefficacy of individuals is affected by the perceived self-efficacy of other individuals as suggested with indirect experience. As teachers are the most common role-models of students, the perceived selfefficacy of teachers is of great importance for the personality development of students (Bandura, 1997; Kiremit, 2006). Furthermore, teachers with a high sense of self-efficacy put effort into satisfying the learning needs of all of their students. Therefore, it is important to research the self-efficacy development of pre-service teachers (Pendergast, Garvis \& Keogh, 2011). Self-efficacy in science teaching can be defined as the judgments and beliefs of teachers about their skills to deliver science teaching in the most effective and efficient manner, and to raise student success (Pajares, 2002; Kurtuluş \& Çavdar, 2010). A sense of self-efficacy in teachers is important to achieve the goals of the 
teaching program in science lessons. Teachers with a high sense of self-efficacy tend to use different teaching methods, conduct research so as to improve their methods and construct student-centered teaching strategies while teachers with a lower sense of self-efficacy deliver teacher-centered lessons and conduct lessons by using only their course books (Henson, 2001; Plourde, 2001).

\section{Rationale}

Teachers, who are among the most important components of learning experiences and a dynamic part of classes that have adopted constructivist learning theory as a principle, should be well-informed in individual and professional perspectives, and should have certain qualifications. Similar to all areas, the status of teachers in respect to reflective teaching and self-efficacy in science teaching is also perceived as important for teacher training programs and the improvement of these. Determining the belief levels of in particular pre-service teachers attending teaching faculties in terms of reflective thinking and self-efficacy could prove important in reviewing the adequacy of current teaching programs and the contents of courses, and to train more competent and qualified teachers in this respect. There are several studies in the literature concerning reflective thinking skills (Bağcioğlu, 2000; Bayrak \& Koçak Usluel, 2011; Duban \& Yanpar Yelken, 2010; Ersözlü, 2008; Fallon \& Brown, 2002; Gipe \& Richards, 1992; Jansen \& Spitzer, 2009; Tok, 2008; Tang, 2000; Wenzlaff, 1994; Şahin, 2009; Köksal \& Demirel, 2008; Lee, 2005; Mewborn, 1999; Phan, 2007; Töman \& Odabaşı Çimer, 2014) and belief in self-efficacy (Aydın \& Boz, 2010; Azar, 2010a; Bursal, 2010; Cerit, 2010; Morrell \& Carroll, 2003; Pendergast et al., 2011; Tschannen-Moran \& Woolfolk Hoy, 2007; Bahçıvan \& Kapucu, 2014; Bleincher \& Lindgren, 2005; Bursal, 2010; Çakiroglu, Cakiroglu \& Boone, 2005; Enochs, Scharmann \& Riggs, 1995; Gencer \& Çakıroğlu, 2007). Some of these studies were conducted in the area of science (Baş, 2013; Dowey, 2013; İlhan \& Sünkür, 2013; Sünkür, Arıbaş, Töman \& Odabaşı Çimer, 2014; Şahin, 2009; Uluçınar Sağır \& Aslan, 2009; Uitto, 2014; Üredi \& Üredi, 2006; Wenner, 2001). However, studies which examine both reflective thinking skills and perceived self-efficacy together are scarce. In one of these studies, Phan (2007) examined the relationship among learning approach, perceived selfefficacy, reflective thinking state and the academic performance of students from a causal perspective. The number of such studies should be increased. In terms of teacher training and teacher efficacy to meet this need, teachers who think reflectively and have a certain level of perceived self-efficacy in their area are needed in all areas, as in the case of science teaching. At this point, it is believed that determining the quality of interaction and the relationship between reflective thinking and selfefficacy would contribute greatly to the area and the literature.

Therefore, the main aim of this study is to investigate the relationship between the characteristics of disposition towards reflective thinking and perceived self-efficacy in the science teaching of preservice science teachers in respect to certain variables.

\section{Method}

\section{Research Design.}

This research, which examines the relationship between perceived self-efficacy and disposition towards reflective thinking in science teaching in pre-service science teachers, was conducted using a relational survey model. The relational survey model is a research model in which the relationship between two or more variables are examined without any intervention (Creswell, 2003; Büyüköztürk, Kılıç Çakmak, Akgün, Karadeniz \& Demirel, 2010). The margins are $2.54 \mathrm{~cm}$ from all sides, with no gutter.

\section{Sample}

In line with the aim of the research, it was planned to include 3rd year students who did not have any previous experience in schools, teaching practice or special teaching methods I lessons and 4th year students who had started to receive these lessons in the study. The study group was selected through 
the purposeful sampling method. Students attending 3rd and 4th years of the science teaching departments at Amasya University (AU), Erciyes University (EU), Necmettin Erbakan University (NEU), and Abant Izzet Baysal University (AIBU) at the end of the 2014-2015 academic year constitute the population. Accessed students represent the sample. The distribution of the sample by universities is given in Table 1.Headings and Subheadings. Left justified headings (10pt, bold). No numbering required. Subheadings (10pt, italic) should lead a paragraph as shown.

Table 1. Characteristics of research group

\begin{tabular}{lcccccccccc}
\hline & \multicolumn{3}{c}{ Gender } & \multicolumn{2}{c}{ Grade } & \multicolumn{3}{c}{ Type of education } & \multicolumn{3}{c}{$\begin{array}{c}\text { Type of high } \\
\text { school }\end{array}$} \\
\cline { 2 - 12 } & & Female & Male & 3 & 4 & Normal & Evening & 1 & 2 & 3 \\
\hline \multirow{2}{*}{ AU } & $\mathrm{N}$ & 153 & 60 & 74 & 139 & 138 & 75 & 173 & 18 & 22 \\
& $\%$ & 71.8 & 28.2 & 34.7 & 65.3 & 64.8 & 35.2 & 81.2 & 8.5 & 10.3 \\
\cline { 2 - 12 } EU & $\mathrm{N}$ & 102 & 29 & 50 & 81 & 89 & 42 & 104 & 26 & 1 \\
& $\%$ & 77.9 & 22.1 & 38.2 & 61.8 & 67.9 & 32.1 & 79.4 & 19.8 & 0.8 \\
\cline { 2 - 11 } NEU & $\mathrm{N}$ & 122 & 32 & 55 & 99 & 106 & 48 & 111 & 28 & 15 \\
& $\%$ & 79.2 & 20.8 & 35.7 & 64.3 & 68.8 & 31.2 & 72.1 & 18.1 & 9.7 \\
\multirow{3}{*}{ AIBU } & $\mathrm{N}$ & 98 & 23 & 44 & 77 & 87 & 34 & 94 & 19 & 8 \\
& $\%$ & 81.0 & 19.0 & 36.4 & 63.6 & 71.9 & 28.1 & 77.7 & 15.7 & 6.6 \\
\hline \multirow{2}{*}{ Total } & $\mathrm{N}$ & 475 & 144 & 223 & 396 & 420 & 199 & 482 & 91 & 46 \\
& $\%$ & 76.7 & 23.3 & 36.0 & 64.0 & 67.9 & 32.1 & 77.9 & 14.7 & 7.4 \\
\hline
\end{tabular}

1: General high school 2: Anatolian-science-teacher high schools 3: Vocational high schools

Six hundred and nineteen students from 4 universities participated in the research. All of the 3rd year students received normal daytime education while some of the 4th year students received evening education. Upon being asked about the type of high school they had graduated from, 1 student from AU, 3 students from EU and, 3 students from NEU stated they had graduated from science high school; 3 students from AU, 5 students from EU, 1 student from NEU and, 1 student from AIBU stated they had graduated from teacher training high school and they were included in the Anatolian high school group in order to facilitate analysis.

Students were asked whether they gave private lessons; 89 students (14.4\%) replied affirmatively while 526 students $(85.0 \%)$ replied negatively. Students were requested to evaluate themselves academically. Thirty eight (6.1\%), $292(47.2 \%), 259(41.8 \%)$ and $30(4.9 \%)$ students evaluated themselves as poor, medium, good and very good, respectively.

\section{Instrumentation}

In this study, two instruments were applied to the participants respectively: (1) Science Teaching Efficacy Belief Instrument (STEBI) and (2) Disposition Towards Reflective Thinking Scale (STRTS).

Science Teaching Efficacy Belief Instrument (STEBI): This is a 5-point Likert scale with two subdimensions which was developed by Enochs and Riggs (1990), and was adapted to Turkish by Özkan, Tekkaya and Çakıroğlu (2002). It has total of 23 items which consist of 13 positive and 10 negative items. Thirteen items in the scale constitute the "Perceived Self-Efficacy in Science Teaching" dimension while the remaining 10 items constitute the "Result Expectation in Science Teaching" dimension. The Cronbach Alpha reliability values of the subdimensions in the original scale were determined as 0.76 and 0.90 , respectively. The reliability of the subdimensions were calculated as 0.77 and 0.86, respectively while the Cronbach Alpha was calculated as 0.79 for the entire scale. The reliability coefficient being higher than 0.75 in educational studies indicates that the measurement tool is within the reliability range (Büyüköztürk et al., 2010). 
Disposition Towards Reflective Thinking Scale (STRTS): This 5-point Likert scale which was developed by Semerci (2007) for pre-service teachers comprises seven subdimensions and 35 items. It consists of 20 negative and 15 positive items. The subdimensions and their corresponding numbers of items and the Cronbach Alpha reliability coefficients of the scale are as follows: Continuous and purposeful thinking: 7 items, 0.79; open-mindedness: 6 items, 0.71; questioning and effective thinking: 5 items, 0.75; teaching responsibility and being scientific: 5 items, 0.77; researcher: 6 items, 0.74; being prescient and sincere: 4 items, 0.67 ; perception of profession: 2 items, 0.35 . Reliability was set as 0.905 for the overall scale. In this research, the reliability coefficients of the sub-factors were found as 0.61 ; $0.75 ; 0.66 ; 0.63 ; 0.68 ; 0.63 ; 0.32$, respectively while the reliability coefficient was calculated as 0.92 for the overall scale.

\section{Data Analysis}

After the student forms that were not completed or provided insufficient data were omitted, the codes were entered as 1: strongly disagree, ... 5: strongly agree in positive items, whereas the codes for negative items were 1 : strongly agree, ... 5: strongly disagree. A statistical package program was used for data analysis. Normal distribution of data was checked with the Kolmogorov Smirnov test. In the relevant test, parametric tests are applicable where p $>0.05$ and the sample is above 30 (Pallant, 2001). Total scores were found to be suitable for analysis through parametric tests. The independent samples t-test was used for comparing pairs and single-factor ANOVA was used for groups higher than two, Pearson correlation analysis was used to determine the relationship among variables and regression analyses were conducted to determine the extent to which independent variables predict dependent variables. The assumptions of relevant tests were controlled. Evaluations were made for a significance level of $\mathrm{p}=0.05$.

\section{Findings}

The relationship between perceived self-efficacy in science teaching and disposition towards creative thinking in students was examined through Pearson correlation analysis. The results are given in Table 2.

Table 2. Correlation analysis results

\begin{tabular}{lccccc}
\hline & $\mathrm{N}$ & $\overline{\boldsymbol{X}}$ & $\mathrm{s}$ & $\mathrm{r}$ & $\mathrm{p}$ \\
\hline STEBI & 619 & 85.69 & 9.43 & 0.582 & 0.000 \\
STRTS & 619 & 144.43 & 17.55 & & \\
\hline
\end{tabular}

A positive significant relationship at medium-level was found between perceived self-efficacy in science teaching and disposition towards reflective thinking of the students constituting the sample $(\mathrm{r}=0.582 ; \mathrm{p}<0.05)$.

The differentiation of perceived self-efficacy in science teaching of pre-service science teachers was examined through independent samples t-test in respect to gender, grade level, type of education whether they gave private lessons. The results are given in Table 3.

Table 3. Comparison of STEBI scores in respect to different variables: t-test results

\begin{tabular}{lccccccc}
\hline & & $\mathrm{N}$ & $X$ & $\mathrm{~s}$ & $\mathrm{~T}$ & $\mathrm{sd}$ & $\mathrm{p}$ \\
\cline { 2 - 8 } Gender & Female & 475 & 85.95 & 9.34 & 1.25 & 617 & 0.213 \\
& Male & 144 & 84.83 & 9.73 & & & \\
\hline \multirow{2}{*}{ Grade } & 3 & 223 & 84.95 & 8.67 & -1.47 & 617 & 0.143 \\
& 4 & 396 & 86.11 & 9.82 & & & \\
\hline \multirow{2}{*}{ Type of } & Normal & 198 & 85.36 & 9.20 & -1.50 & 394 & 0.134 \\
education & Evening & 198 & 86.84 & 10.36 & & & \\
\hline Giving & Yes & 89 & 87.47 & 10.11 & 1.83 & 613 & 0.067 \\
\hline
\end{tabular}




\begin{tabular}{lllll}
\hline $\begin{array}{l}\text { private } \\
\text { lessons }\end{array}$ & No & 526 & 85.51 & 9.20 \\
\hline
\end{tabular}

When the perceived self-efficacy in science teaching of students was compared in respect to gender, it was found that there was no significant difference between the scores of male and female students ( $t 617=1.25 \mathrm{p}>0.05$ ). There was no significant difference between the mean scores of perceived selfefficacy of 3rd and 4th year students according to grade level either ( $t 617=-1.47 ; p>0.05$ ). As there was no evening education students in the 3rd year while 4th year students attended to either normal daytime or evening education, only 4 th year students were selected to examine the effect of type of education. Again, no significant difference was determined between the mean perceived self-efficacy in science teaching scores ( $\mathrm{t} 394=-1.502 ; \mathrm{p}>0.05)$. When the subdimensions were examined, a significant difference in perceived self-efficacy in science teaching was not found in respect to gender, grade level or type of education. There was not a significant difference in the perceived self-efficacy of students based on whether students gave private lessons; however, those who gave private lessons had a higher mean score ( $t 613=1.83 ; p>0.05$ ). As for the subdimensions, the mean score of perceived self-efficacy in science teaching of the students who delivered private lessons was found as 51.35 whereas that of students who did not give private lessons was 49.64, indicating a significant difference between $(\mathrm{t} 613=2.236 ; \mathrm{p}=0.026<0.05)$. The difference was not significant in respect to the dimension of result expectation.

Single-factor variance analyses were conducted in order to examine the perceived self-efficacy in science teaching of students based on the type of high school they had graduated from, the universities they attended and their perception of academic success. The results are given in Table 4.

Table 4. Comparison of STEBI scores in respect to different variables: ANOVA results

\begin{tabular}{llccccccc}
\hline \multirow{2}{*}{$\begin{array}{l}\text { Type of } \\
\text { high school }\end{array}$} & General & 482 & 85.58 & 9.37 & 0.139 & 3 & 0.936 & \\
& FLI & 77 & 86.10 & 9.49 & & 615 & & \\
& Vocational & 46 & 86.28 & 8.83 & & & & \\
& Teacher & 14 & 85.28 & 13.38 & & & & Source of \\
Difference
\end{tabular}

FLI = Foreign language intensive high schools

According to the type of high school they have graduated from, students' perceived self-efficacy in science teaching did not indicate any significant difference in total or in subdimensions (F3-615=0.139; $\mathrm{p}>0.05$ ). A significant difference was found in the self-efficacy of students based on receiving education at different universities (F3-615=9.433; $\mathrm{p}<0.05)$. This difference was found between the students at Erciyes University and other universities and was not in favor of the students of Erciyes University. Significant differences were found in the science self-efficacy subdimension F3-615=8.581 $\mathrm{p}=0.000$; between AU-EU; NEU-EU and AIBU-EU; and in the result expectation subdimension F3$615=4.234 \mathrm{p}=0.006$ between NEU-EU. A significant difference also existed in the perception of students towards their own academic success (F3-615=7.681; $\mathrm{p}<0.05)$. A difference was found between those who evaluated their success as good and medium, and those who evaluated it as very good and 
poor. A significant difference was found in self-efficacy in the science teaching subdimension (F3$615=8.565 \mathrm{p}=0.000$ ) between the very good-poor/medium and good-low/medium groups.

The t-test results for the variation in disposition towards reflective thinking (STRTS) in students based on gender, grade and type of education are given in Table 5.

Table 5. Comparison of STRTS scores in respect to different variables: $t$-test results

\begin{tabular}{llrrrrrc}
\hline \multirow{2}{*}{ Gender } & & $\mathrm{N}$ & $\bar{X}$ & $\mathrm{~s}$ & $\mathrm{~T}$ & $\mathrm{sd}$ & $\mathrm{p}$ \\
\cline { 2 - 8 } & Female & 475 & 145.36 & 16.82 & 2.41 & 617 & 0.016 \\
& Male & 144 & 141.35 & 19.48 & & & \\
\hline \multirow{2}{*}{ Trade } & 3 & 223 & 143.26 & 17.94 & -1.23 & 617 & 0.218 \\
& 4 & 396 & 145.07 & 17.31 & & & \\
\hline education & Evening & 198 & 146.24 & 16.09 & & & 0.181 \\
Giving & Yes & 89 & 146.48 & 17.62 & 1.162 & 613 & 0.246 \\
private & No & 526 & 144.15 & 17.50 & & & \\
lessons & & & & & & & \\
\hline
\end{tabular}

The comparison of disposition towards reflective thinking indicates a significant difference in favor of females $(t 617=2.41 ; p<0.05)$. Female students more predominantly think in a reflective manner. Upon reviewing the subdimensions, no significant difference was found in the being continuous and purposeful, individual responsibility in education, being a researcher, and being prescient and sincere subdimensions in males and females as opposed to the other dimensions. In the dimension of openmindedness, the mean scores of females and males were 25.72 and 24.46, respectively $(t 617=3.093$; $\mathrm{p}=0.002$ ). In questioning and effective thinking $X$ females $=21.46$ and $X$ males $=20.61$ ( $\mathrm{t} 617=2.580$; $\mathrm{p}=0.011)$ and in professional perception $X$ females $=8.13 X$ males $=7.71 \quad(t 617=2.388 ; p=0.017)$ the results indicate that these significant differences are in favor of female students. No significant difference between 3rd and 4th year students were found in respect to STRTS scores (t617=-1.23; $\mathrm{p}>0.05)$. There were no significant differences in subdimensions either. No significant difference between normal daytime and evening education was found in 4th grade students (t394=-1.34; $p>0.05$ ). Significant differences were identified in certain subdimensions. The mean scores of evening education and normal daytime education were 28.84 and 28.16, respectively in the being continuous and purposeful subdimension ( $\mathrm{t} 617=-2.246$; $\mathrm{p}=0.025$ ); while thre were $X$ evening $=25.04$ and $X$ normal=24.45 in the being a researcher subdimension ( $t 617=-2.034 ; \mathrm{p}=0.042)$. As to whether they gave private lessons, no difference was found in respect to disposition towards reflective thinking in the subdimensions or in the total score ( $\mathrm{t} 613=1.162 ; \mathrm{p}=0.246)$.

The results of the ANOVA conducted to compare the disposition of students towards reflective thinking based on graduated high school type, university and perception of academic success are given in Table 6.

Table 6. Comparison of STRTS scores in respect to different variables: ANOVA results

\begin{tabular}{clccccccc}
\hline & & $\mathrm{N}$ & $\bar{X}$ & $\mathrm{~s}$ & $\mathrm{~F}$ & $\mathrm{sd}$ & $\mathrm{p}$ & $\begin{array}{c}\text { Source of } \\
\text { Difference }\end{array}$ \\
\hline \multirow{3}{*}{$\begin{array}{c}\text { Type of } \\
\text { high school }\end{array}$} & General & 482 & 144.15 & 17.54 & 0.750 & 3 & 0.522 & \\
& VLI & 77 & 144.51 & 18.37 & & 615 & & \\
& Vocational & 46 & 147.95 & 14.29 & & & & \\
\hline \multirow{2}{*}{ University } & 14 & 142.00 & 22.80 & & & & AU-EU \\
& AU & 213 & 143.34 & 17.57 & 19.86 & 3 & 0.000 & NEU-EU \\
& EU & 131 & 134.93 & 19.14 & & 615 & &
\end{tabular}




\begin{tabular}{ccccccccc} 
& NEU & 154 & 149.76 & 15.14 & & & & AIBU-EU \\
& AIBU & 121 & 146.30 & 14.50 & & & \\
\hline $\begin{array}{c}\text { Perception } \\
\text { of academic } \\
\text { success }\end{array}$ & Poor & 38 & 139.55 & 18.57 & 6.281 & 3 & 0.000 & $\begin{array}{c}\text { Good-medium } \\
\text { Very good- } \\
\text { poor }\end{array}$ \\
& & & & & & 615 & & $\begin{array}{c}\text { Very good- } \\
\text { medium }\end{array}$ \\
\hline
\end{tabular}

According to the type of high school they graduated from, students' disposition towards reflective thinking did not indicate any significant difference (F3-615 $=0.750 ; \mathrm{p}>0.05)$. A significant difference in the subdimension of being prescient and sincere was found between types of high school (F3$615=2.721 ; \mathrm{p}=0.044)$. According to the attended university, the disposition of students toward reflective thinking indicated a significant difference (F3-615=19.86; $\mathrm{p}<0.05$ ). Erciyes University students had a lower level of disposition towards reflective thinking as compared to other universities. Differences in disposition towards reflective thinking were found in all of the subdimensions according to university (F3-615=14.137; F3-615=19.955; F3-615=16.574; F3-615=10.812; F3-615=15.184; F3-615=8.017; F3-615 $=6.382 \mathrm{p}=0.000$ respectively for all subdimensions). EU results were lower than those of other universities in all of the dimensions. A significant difference between students was found when they were compared based on their perception of academic success (F3$615=6.281 ; p=0.000$ ). The differences between those who evaluate themselves as good and medium; and those who evaluate themselves as very good and as low-medium were significant. Significant differences were found in all of the subdimensions except for professional perception. The $\mathrm{F}$ values of the subdimensions are respectively as follows: F3-615=5.356; F3-615=5.574; F3-615=2.394; F3-615=6.198; F3-615=5.827; F3-615=4.677 $\mathrm{p}<0.05$. Differences were found among the good-medium, very goodmedium and very good-poor groups.

The effect of variables that predict the disposition of students towards reflective thinking was examined through multiple regression analysis. The results are given in Table 7.

Table 7. Multiple regression results for the prediction of disposition towards reflective thinking

\begin{tabular}{|c|c|c|c|c|c|c|c|}
\hline & \multicolumn{3}{|c|}{ Std. } & \multirow{2}{*}{$\mathrm{T}$} & $\mathrm{p}$ & Binary $\mathrm{r}$ & \multirow{2}{*}{ Partial r } \\
\hline & $\frac{\mathrm{B}}{48072}$ & Error & $\beta$ & & $\frac{p}{0000}$ & Dimary 1 & \\
\hline Constant & 48.072 & 0.822 & - & 7.047 & 0.000 & & \\
\hline Grade & 0.026 & 1.391 & 0.001 & 0.019 & 0.985 & 0.050 & 0.001 \\
\hline Type of high school & 0.516 & 0.805 & 0.021 & 0.640 & 0.522 & 0.030 & 0.026 \\
\hline Academic success ev. & 1.645 & 0.856 & 0.064 & 1.922 & 0.055 & 0.170 & 0.077 \\
\hline STEBI & 1.057 & 0.062 & 0.568 & 17.014 & 0.000 & 0.582 & 0.566 \\
\hline Type of education & 0.755 & 1.434 & 0.020 & 0.527 & 0.599 & 0.075 & 0.021 \\
\hline
\end{tabular}

Grade level, type of education, type of graduated high school, academic success evaluation and perceived self-efficacy (STEBI) are related to disposition towards reflective thinking at medium level. These variables in total explain $34.4 \%$ of the variance in disposition towards reflective thinking. Based on the standardized regression coefficient, the order of importance of predictive variables on STRTS is self-efficacy, academic success evaluation, type of graduated high school and type of education. Based on the t-test results, it could be suggested that only perceived self-efficacy has a significant effect on STRTS. The regression equation could be given as follows:

STRTS $=48.072+0.026$.grade +0.516 type of high school +1.645 ac.suc.ev. +1 ,057STEBI + 0.755typeofeducation 


\section{Discussion}

Differences in self-efficacy and disposition towards reflective thinking scores according to certain variables were observed in this research, which examined the characteristics of disposition towards reflective thinking and perceived self-efficacy in science teaching of pre-service science teachers in respect to different variables.

A positive significant relationship at medium-level was found between perceived self-efficacy in science teaching and disposition towards reflective thinking in the students constituting the sample. Accordingly, it is seen that the higher the perceived self-efficacy of pre-service teachers in science is, the greater their skills in reflective thinking improve. Similarly, Phan (2007) demonstrated that perceived self-efficacy directly predicts and determines reflective thinking.

When perceived self-efficacy in the science teaching of students was compared in respect to gender, it was observed that there was no significant difference between the scores of male and female students. The finding that perceived self-efficacy does not differ based on genders is parallel to the research findings that found no significant difference between males and females (Milner \& Woolfolk-Hoy, 2002; Altunçekiç, Yaman \& Koray, 2005; Çetin, 2007; Ekici, 2008; Uluçınar Sağır \& Aslan, 2009; Azar, 2010b; Yenice, 2012;) while they conflict with the study findings that suggest a difference between males and females in respect to self-efficacy (Bandura, Schunk, 1981; Jones \& Wheatley, 1990; Scholz, Gutierrez-Dona, Sud \& Schwarzer, 2002; Morgil, Seçken, \& Yücel, 2004; Üredi \& Üredi, 2006; Britner \& Pajares, 2006). Although the results of studies that examine the perceived self-efficacy of teachers do not align in this context, the fact that no difference was found in the perceived self-efficacy of science teachers in respect to genders could be justified with the evolving role of the traditional woman in Turkish society, women being prominent in society with academic success and a lack of professional restriction in our country in terms of genders.

No significant difference in the mean scores of perceived self-efficacy of students was found according to the grade level variable either. Studies conducted by Berkant and Ekici (2007), Cerit (2010) and Yenice (2012) support this finding. Although it was expected that pre-service teachers would be positively affected by the high number of pedagogic field lessons in the last 2 years of their courses, the fact that perceived self-efficacy did not vary based on the grade levels of students could be interpreted as that the education received by pre-service teachers in the last 2 years did not cause a difference in perceived self-efficacy. The studies conducted by Durdukoca, (2010) and Uluçınar Sağır and Aslan (2009) determined that the perceived self-efficacy of pre-service teachers was directly proportional with increase in grade level. These differences were attributed to the lessons received by pre-service teachers in their respective academic terms.

While no significant difference was observed in the perceived self-efficacy of students based on whether they gave private lessons, and the type of graduated high school, significant differences were found based on the universities attended. The results yielded which were not in favor of Erciyes University, support the findings of research to examine teaching self-efficacy based on questioning of science and technology pre-service teachers conducted by İnaltekin and Akçay (2912), the findings of research to examine the perceived self-efficacy of secondary education mathematics and pre-service science teachers conducted by Azar (2010a), and the results of the research conducted by Akbaş and Çelikaleli (2006) on class pre-service teachers; however they do not support the results of research by Kiremit (2006) which examined the perceived self-efficacy in biology teaching of pre-service science teachers. In spite of the unavailability of any research that examines the perceived self-efficacy of preservice science teachers attending different universities in the literature review, the difference may be suggested to stem from physical and academic reasons. The effect of the similarity of expectations of pre-service teachers towards their field of teaching and the shared program at university is suggested 
as the reason for the lack of a significant difference in perceived self-efficacy of teachers based on graduated high-school (Özdemir, 2008).

Significant differences were observed between the academic success perceptions and perceived selfefficacy scores of students. Significant differences were determined between those who evaluated their success as good and medium, and those who evaluated it as very good and poor. Several researchers analyzed the relationship between perceived self-efficacy and academic success (Andrew, 1998; Spieker \& Hinsz, 2004; Lane, Lane \& Kyprianou, 2004; Canpolat \& Kazak Çetinkalp, 2011), and the yielded result was similar in respect to the effect of perceived self-efficacy of students on increasing their academic success.

A significant difference in favor of female students was observed in the comparison of disposition towards reflective thinking based on the gender variable. Female students more predominantly think in a port this finding. For instance, Duban and Yanpar Yelken (2010) found that female pre-service teachers had a higher level of disposition towards reflective thinking as compared to male pre-service teachers. Again, the research conducted by Hasırcı and Sadık (2011) determined that female teachers have a higher level of reflective thinking than male teachers. The basic reasons for this situation could be that females have a higher level of professional confidence in modern societies and perceive themselves as more sufficient in the teaching profession as compared to males (Akbaş \& Çelikkaleli, 2006). The research conducted by Saygilı and Tehneldere (2014) found that the characteristics of the reflective thinking subdimension did not have any significant differences based on the gender of teachers.

No significant difference between 3rd and 4th grades were found in respect to disposition towards reflective thinking scores. Again, no significant difference was observed in disposition towards reflective thinking between students attending normal daytime and evening education. The reason for the lack of difference in reflective thinking characteristics between grade levels could be suggested as the unavailability of sufficient education on reflective thinking delivered at the higher education institutions of the pre-service teachers (Alp \& Taşkın, 2012). It could be said that, in particular the lessons delivered at 3rd and 4th grades for science education are not effective in improving students' reflective thinking skills.

The disposition towards reflective thinking did not indicate any significant difference according to the type of high school students graduated from while significant differences were determined based on the universities attended. This result suggests that while lessons received in high school education do not cause any differentiation in disposition towards reflective thinking, the lessons received at different universities and different education faculties cause a differentiation in disposition towards reflective thinking. Accordingly, it is assumed that the forms of teaching practice lessons that are received for field education in the 3rd and 4 th grades have a particular effect. The most important responsibility here belongs to the academic staff that lectures in the faculties of education (Duban \& Yanpar Yelken, 2010). The development of reflective thinking skill could be supported by using diaries and videos in lessons such as school experience and teaching practice (Şahin, 2009). Moreover, Norton (1997) revealed a positive relationship between effective teaching and reflective thinking in his research.

Significant differences were found in the disposition of pre-service science teachers towards reflective thinking based on their levels of academic success. This situation indicates that an increase in the academic success of pre-service teachers can also cause a differentiation in disposition towards reflective thinking. Baş (2013) determined that reflective thinking skills for problem solving constitute a significant predictor of academic success in science and technology lessons in his research conducted on the relationship between the reflective thinking skills of elementary students for 
problem solving and their academic success scores obtained from science and technology lessons. The improved reflective thinking skills of students lead to students who question more and spend more time on problems (Kizılkaya, 2009). A study conducted by Tok (2008) found that students who received education through activities that support reflective thinking had increased success in science lessons.

It was determined that the highest variable for predicting the disposition of students towards reflective thinking is their perceived self-efficacy. Similar results were obtained by Sarı Uzun, Sezen Yüksel and Dost (2013) in their study carried out with mathematics pre-service teachers.

\section{Conclusion and Suggestions}

There is a positive significant relationship at medium-level between perceived self-efficacy in science teaching and disposition towards reflective thinking in pre-service science teachers. Perceived selfefficacy in science teaching does not have any significant difference in respect to gender, grade level, type of education, giving private lessons or type of high school. However, the difference based on the universities and sense of academic success of pre-service teachers was found to be significant. Disposition towards reflective thinking is not significantly different based on grade, type of education, type of high school or giving private lessons. Nonetheless, significant differences are observed in respect to gender, universities and sense of academic success. Grade level, type of education, type of high school, perception of success and perceived self-efficacy together explain $34.4 \%$ of the variance in disposition toward reflective thinking.

The suggestions given below are made based on the research results:

- Attention should be focused on practices to improve the self-efficacy of pre-service teachers in respect to science teaching.

- Activities that improve reflective thinking may be used to help pre-service teachers to improve their reflective thinking skills. Academic staff should be encouraged to create such environments.

- In addition to determining the reflective thinking skills of pre-service teachers, studies that aim at determining whether or not the education delivered in education faculties instills reflective teacher characteristics in various areas should be conducted.

- According to this study, studies should be carried out in order to reveal the basic reasons for the differences between universities in respect to perceived self-efficacy in science teaching and reflective thinking disposition, and to eliminate these differences.

- In the framework of the research result indicating that female pre-service teachers have a higher level of disposition towards reflective thinking as compared to male pre-service teachers, activities should be carried out so as to enhance the disposition of male preservice teachers towards reflective thinking.

- The relationship between perceived self-efficacy and disposition towards reflective thinking of pre-service teachers from different fields could be studied.

\section{References}

Akbaş, A., \& Çelikkaleli, Ö. (2006). Sınıf öğretmeni adaylarının fen öğretimi özyeterlik inançlarının cinsiyet, öğrenim türü ve üniversitelerine göre incelenmesi. Mersin Üniversitesi Eğitim Fakültesi Dergisi, 2(1), 98-110.

Alp, S., \& Taşkın, Ç. Ş. (2012). Yansıtıcı düşünce: sınıf öğretmenlerinin görüşleri üzerine nitel bir araştırma. [Critical thinking and problem solving: teachers' use of reflective thinking].Buca Eğitim Fakültesi Dergisi, 33, 134-146.

Altunçekiç, A., Yaman, S. \& Koray, O. (2005). Öğretmen adaylarının öz-yeterlik inanç düzeyleri ve problem çözme becerileri üzerine bir araştırma (Kastamonu ili örneği) [The research on 
prospective teachers' self effıcacy belief level and problem solving skills]. Kastamonu Eğitim Dergisi, 13(1), 93-102.

Andrew, S. (1998). Self-efficacy as a predictor of academic performance in science. Journal of Advanced Nursing, 14(6), 436-442.

Aydın, S., \& Boz, Y. (2010). Pre-service elementary science teachers' science teaching efficacy beliefs and their sources. [Pre-service elementary science teachers' science teaching efficacy beliefs and their source]. İlköğretim Online, 9(2),694-704.

Azar, A. (2010a). In-service and pre-service secondary science teachers self-efficacy beliefs about science teaching. Educational Research and Reviews, 5(4), 172-185.

Azar, A. (2010b). Ortaöğretim fen bilimleri ve matematik öğretmeni adaylarının öz yeterlilik inançları. ZKÜ Sosyal Bilimler Dergisi, 6(12): 235-252.

Bağcıŏlu, G. (2000). Öğretmen adaylarında yansıtıcı düşünmeyi geliştirici etkinlikler. VIII. Ulusal Eğitim Bilimleri Kongresi. (1-3 Eylül 1999). Trabzon.

Bahçıvan, E., \& Kapucu, S. (2014). Turkish preservice elementary science teachers' conceptions of learning science and science teaching efficacy beliefs: is there a relationship?. International Journal of Environmental and Science Education, 9(4), 429-442.

Bandura, A. \& Schunk, D.H. (1981). Cultivating competence, self efficacy and intrinsic interest through self-motivation. Journal of Personality and Social Psychology, 41, 586-598.

Baş, G. (2013). İlköğretim öğrencilerinin problem çözmeye yönelik yansıtıcı düşünme becerileri ile fen ve teknoloji dersi akademik başarıları arasındaki ilişkinin yapısal eşitlik modeli ile incelenmesi. [Investigating the correlation between elementary students' reflective thinking skills towards problem solving and academic success in science and technology course with structural equation modeling]. Hasan Ali Yücel Eğitim Fakültesi Dergisi, 20, 1-12.

Bayrak, F. \& Koçak Usluel, Y. (2011). Ağ günlük uygulamasının yansıtıcı düşünme becerisi üzerine etkisi. [The effect of blogging on reflective thinking skill]. Hacettepe Üniversitesi Eğitim Fakültesi Dergisi, 40, 93-104.

Berkant, H. \& Ekici, G. (2007). Sınıf öğretmeni adaylarının fen öğretiminde öğretmen öz-yeterlik inanç düzeyleri ile zeka türleri arasındaki iliksinin değerlendirilmesi. Çukurova Üniversitesi Sosyal Bilimler Enstitüsü Dergisi, 16 (1), 113-132.

Bleicher, R. E., \& Lingren, J. (2005). Success in science learning and preservice science teaching selfefficacy. Journal of Science Teacher Education, 16(3), 205-225.

Britner, S. L. \& Pajares, F. (2006). Sources of science self-efficacy beliefs of middle school students. Journal of Research in Science Teaching, 43(5), 485-499.

Bursal, M. (2010). Turkısh preservice elementary teachers'self-efficacy beliefs regardıng mathematıcs and science teaching. International Journal of Science and Mathematics Education, 8(4), 649666.

Canpolat, A. M. \& Kazak Çatinkalp, Z. (2011). İlköğretim II. kademe öğrenci-sporcuların başarı algısı ve öz-yeterlik düzeyleri arasındaki ilişki. Selçuk Üniversitesi Beden Eğitimi ve Spor Bilim Dergisi, 13 (1), 14-19.

Cerit, Y. (2010). Teacher efficacy scale: the study of valıdity and reliability and preservice classroom teachers'self efficacy beliefs. Journal of Theory and Practice in Education, 6(1), 68-85.

Creswell, J.W. (2003). Research design qualitative, quantitative and mixed methods approaches, Second Edition, Sage Publications.

Çakiroglu, J., Çakiroglu, E., \& Boone, W. J. (2005). Pre-service teacher self-efficacy beliefs regarding science teaching: a comparison of pre-service teachers in turkey and the USA. Science Educator, 14(1), 31-40.

Çetin, B. (2007). Sınıf öğretmenliği anabilim dalı 3. sınıf öğrencilerinin matematik ve fen bilgisi öğretimi öz-yeterliklerinin incelenmesi. VI. Ulusal Sınıf Öğretmenliği Eğitimi Sempozyumu. Anadolu Üniversitesi Eğitim Fakültesi, 27-29 Nisan 2007.

Dewey, J. (1933). How we think: A restatement of the relation of reflective thinking to the educative process. Boston: D. C. Heath Publication. 
Dowey, A.L. (2013). Attitudes, interests, and perceived self-efficacy toward science of middle school minority female students considerations for their low achievement and participation in STEM disciplines, UC San Diego Electronic Theses and Dissertations,

Duban, N. \& Yanpar Yelken, T. (2010). Öğretmen adaylarının yansıtıcı düşünme eğilimleri ve yansıtıcı öğretmen özellikleriyle ilgili görüşleri. Çukurova.Üniversitesi Sosyal Bilimleri Enstitüsü Dergisi, 19(2), 343-360.

Durdukoca, Ş.F. (2010). Sınıf öğretmeni adaylarının akademik öz yeterlik algılarının çeşitli değişkenler açısından incelenmesi. [Analysis of academic self-efficiency beliefs of elementary school teacher candidates using different variables]. Abant İzzet Baysal Üniversitesi Dergisi, 10(1), 69-77.

Ekici, G. (2008). Sınıf yönetimi dersinin öğretmen adaylarının öğretmen öz-yeterlik algı düzeyine etkisi. [The effects of the classroom management lesson on preservice teachers' teacher sense of self effıcacy].Hacettepe Eğitim Fakültesi Dergisi, 35, 98-110.

Enochs, L.G., Scharmann, L.C. \& Riggs, I.M., (1995). The relationship of pupil control to preservice elementary science teacher self-efficacy and outcome expectancy. Science Education,79, 63-75.

Ersözlü, Z.N. (2008). Yansıtıcı düşünmeyi geliştirici etkinliklerin ilköğretim 5. sınıf öğrencilerinin sosyal bilgiler dersindeki akademik başarılarına ve tutumlarına etkisi. Yayımlanmamış Doktora Tezi, Frrat Üniversitesi Sosyal Bilimler Enstitüsü, Elazığ.

Fallon, M. A. \& Brown, S. C. (2002). Crossing over from student teaching to first year teaching. School of Education, 4 (1), 37-46.

Gencer, A. S. \& Cakiroglu, J. (2007). Turkish pre-service science teachers' efficacy beliefs regarding science teaching and their beliefs about classroom management. Teaching and Teaching Education, 23, 664-675.

Gipe, J. P. \& Richards, J. (1992). Reflective thinking and growth in novices' teaching abilities. Journal of Educational Research, 86 (1), 52-57.

Gözütok, F. D. (2006). Öğretim ilke ve yöntemleri. Ankara: Ekinoks Yayınları.

Henson R. K.(2001). Teacher self-efficacy: substantive implications and measurement dilemmas. Paper presented at the annual meeting of the educational research exchange.

Jansen, A. \& Spitzer, S. M. (2009). Prospective middle school mathematics teachers' reflective thinking skills: descriptions of their students' thinking and interpretations of their teaching. Journal of Mathematics Teacher Education,12, 133-151.

Kızılkaya, G. \& Aşkar, P. (2009). Problem çözmeye yönelik yansıtıcı düşünme becerisi ölçeğinin geliştirilmesi. [The development of a reflective thinking skill scale towards problem solving].Eğitim ve Bilim, 34 (154), 82-92.

Kiremit, H. (2006). Fen bilgisi öğretmenliği öğrencilerinin biyoloji ile ilgili özyeterlik inançlarının karsılaştırılması. Yayınlanmamış Doktora Tezi, Dokuz Eylül Üniversitesi Eğitim Bilimleri Enstitüsü, İzmir.

Köksal, N. \& Demirel, Ö. (2008). Yansıtıcı düşünmenin öğretmen adaylarının öğretmenlik uygulamalarına katkıları. [The contributions of reflective thinking to pre-service teachers' teaching practice]. Hacettepe Üniversitesi Eğitim Fakültesi Dergisi, 34, 189-203.

Kuit, J. A., Reay, G., \& Freeman, R. (2001). Experinces of reflective teaching. Active Learning In Higher Education, 2, 128-142.

Kurtuluş, N. \& Çavdar, O. (2010). Öğretmen adaylarının fen öğretimine yönelik öz yeterlilikleri, [Selfefficacy beliefs of teacher candidates towards science teaching]. E- journal of New World Sciences Academy, 5(3), 1302-1315.

Özkan,Ö.,Tekkaya, C. \& Çakıroğlu, J. (2002). Fen bilgisi aday öğretmenlerin fen kavramlarını anlama düzeyleri, fen öğretimine yönelik tutum ve öz yeterlik inançları, V. Fen ve Matematik Kongresi, Ankara.

Hasırcı, Ö.K. \& Sadık, F. (2011). Sınıf öğretmenlerinin yansıtıcı düşünme eğilimlerinin incelenmesi. Çukurova Üniversitesi Sosyal Bilimler Enstitüsü Dergisi, 20(2), 195-210. 
İnaltekin, T. \& Akçay, H. (2012). Fen ve teknoloji öğretmenliği adaylarının sorgulamaya dayalı fen öğretimi özyeterliliklerinin incelenmesi. X. Ulusal Fen ve Matematik Eğitimi Kongresi. Niğde Üniversitesi Eğitim Fakültesi, 27-30 Haziran 2012.

Jones, M.G. \& Wheatley, J. (1990). Gender differences in teacher-student interactions in science classrooms. Journal of Research in Science Teaching, 27(9), 861-874.

Kızılkaya, G. (2009). Yansitıcı düşünme etkinlikleri ile desteklenmiş web tabanlı öğrenme ortamlarının problem çözme üzerine etkisi. Yayımlanmamış doktora tezi, Hacettepe Üniversitesi Sosyal Bilimler Enstitüsü, Ankara.

Lane, J., Lane, A. M. \& Kyprianou, A. (2004). Self-efficacy, self-esteem and their impact on academic performance. Social Behavior and Personality, 12 (3), 247- 256

Lee, H. J. (2005). Understanding and assessing prespective teachers' reflective thinking. Teaching and Teacher Education, 21, 699-715.

Lin, X. D., Hmelo, C., Kinzer, C. K., \& Secules, T. J. (1999). Designing technology to support reflection. Educational Technology Research and Development, 47(3), 43-62.

Loughran, J. J. (1996). Developing reflective practice: Learning about teaching and learning through modelling. London: The Falmer Press.

Mewborn, D. S. (1999). Reflective thinking among preservice elementary mathematics teachers. Journal of Research in Mathematics Education, 30(3), 316-341.

Milner H. R. \& Woolfolk-Hoy A. (2003). Teacher self efficacy retaining talented teachers: A case study of an African American teacher. Teaching and Teacher Education, 19, 203-276.

Morgil, İ., Seçken, N. \& Yücel, A.S. (2004). Kimya öğretmen adaylarının öz-yeterlik inançlarının bazı değişkenler açısından incelenmesi. [Based on some investıgatıon of self-efficacy beliefs of preservice chemistry teachers variables]. BAÜ Fen Bilimleri Enstitüsü. Dergisi, 6(1), 62-72.

Morrell, P. D., \& Carroll, J. B. (2003). An extended examination of preservice elementary teachers' science teaching self-efficacy. School Science and Mathematics, 103(5), 246-251.

Norton, J. L. (1994). Creative thinking and locus of control as predictors of reflective thinking in preservice teachers. Retreived 13.04.2015 from http://files.eric.ed.gov/fulltext/ED366579.pdf

Özdemir, S.M. (2008). Sınıf öğretmeni adaylarının öğretim sürecine ilişkin öz-yeterlik inançlarının çeşitli değişkenler açısından incelenmesi. [An investigation of prospective primary teachers' self-efficacy beliefs regarding teaching process in terms of certain variables].Kuram ve Uygulamada Eğitim Yönetimi, 54, 277-306.

Pajares (2002). Self-efficacy beliefs in academic contexts: An outline. Retreived 14.8.2014,

from http://www.uky.edu/ eushe2/Pajares/efftalk.html.

Pendergast, D., Garvis, S., \& Keogh, J. (2011). Pre-service student-teacher self-efficacy beliefs: An insight into the making of teachers. Australian Journal of Teacher Education, 36(12), 45-58.

Phan, H. P. (2007). An examination of reflective thinking, learning approaches, and self-efficacy beliefs at the university of the south pacific: A path analysis approach. Educational Psychology: An International Journal of Experimental Educational Psychology, 27(6), 789-806.

Plourde, L.A.(2001). The genesis of science teaching in the elementary school: the influence of student teaching. Retreived 13.01.2015 from http://files.eric.ed.gov/fulltext/ED453083.pdf\#page=1472

Sarı Uzun, M., Sezen Yüksel, N. \& Dost, Ş. (2013). Investigation of pre-service investigation of preservice teachers' mathematics teaching efficacy beliefs in terms of their reflective thinking tendencies. Procedia-Social and Behavioral Sciences 106, 1595-1602.

Saygıll, G. \& Tehneldere, S. (2014). Eğitim çalışanlarının yansıtıcı düşünme becerilerinin çeşitli değişkenler açısından incelemesi. [Examination of reflective thinking styles of education emloyees in terms of some variables]. Mehmet Akif Ersoy Üniversitesi Sosyal Bilimler Enstitüsü Dergisi, 6(11), 192-202.

Scholz, U., Gutierrez- Dona, B., Sud, S. \& Schwarzer, R. (2002). Is general self efficacy a universal construct? European Journal of Psychological Assessment, 18 (3), 242-251.

Spieker, C. J. \& Hinsz, V. B. (2004). Repeated Success and Failure Influences on SelfEfficacy and Personal Goals. Social Behavior and Personality, 32 (2), 191-198. 
Sünkür, M. Ö., Arıbaş, S., İlhan, M. \& Sünkür, M. (2013). Tahmin et- gözle-açikla stratejisi ile desteklenmiş yansıtıcı düşünmeye dayalı etkinliklerin 7. sınıf öğrencilerinin fen ve teknoloji dersine yönelik tutumlarına etkisi. [The effects of actıvitıes based on reflectıve thınkıng assısted by prediction-observation-explanation strategy on the science and technology course attitudes of 7th grade students].Buca Eğitim Fakültesi Dergisi, 36, 130-141.

Şahin, Ç. (2009). Fen bilgisi öğretmen adaylarının yansıtıcı düşünme yeteneklerine göre günlüklerinin incelenmesi. [An examination of journals of prospective science teachers according to their reflectinh thinking skills]. Hacettepe Üniversitesi Eğitim Fakültesi Dergisi, 36, 225-236.

Tang, C. (2002). Reflective diaries as a means of facilitating and assessing reflection, Educational Development Centre, The Hong Kong Polytechnic University.

Tok, Ş. (2008). Yansıtıcı düşünmeyi geliştirici etkinliklerin öğretmen adaylarının öğretmenlik mesleğine yönelik tutumlarına, performanslarına ve yansıtmalarına etkisi. [The impact of reflective thinking activities on student teachers' attitudes toward teaching profession, performance and reflections]. Eğitim ve Bilim, 33(149), 104-117.

Töman, U. \& Odabaşı Çimer, S. (2014). Fen bilgisi öğretmen adaylarının yansıtııı düşünme düzeylerine göre incelenmesi. [Investigation by level of pre-service science teachers' reflective thinking].Route Educational and Social Science Journal, 1(2), 116-125.

Tschannen-Moran, M., \& Woolfolk Hoy, A. (2007). The differential antecedents of self- efficacy beliefs of novice and experienced teachers. Teaching and teacher Education, 23, 944- 956.

Uitto, A. (2014). Interest, attitudes and self-efficacy beliefs explaining upper-secondary school students' orientation towards biology-related careers, International Journal of Science and Mathematics Education, 12(6), 1425-1444.

Uluçınar Sağır, Ş. \& Aslan, O. (2009). Fen bilgisi öğretmen adaylarının öz yeterlik inançlarının çeşitli değişkenler açısından incelenmesi, [The examİnatıon of preservice science teachers' self efficacy beliefs with respect to different variables]. E-Journal of New World Sciences Academy,4 (2), 465-475.

Ünver, G. (2003). Yansıtıcı düşünme. Ankara: Pegem Yayınevi.

Üredi, I. \& Üredi L., (2006). Sınıf öğretmeni adaylarının cinsiyetlerine, bulundukları sınıflara ve başarı düzeylerine göre fen öğretimine ilişkin öz-yeterlik inançlarının karşılaştırılması. Yeditepe Üniversitesi Eğitim Fakültesi Dergisi. 1(2), 1-8.

Wenzlaff, T. (1994). Training the student to be a reflective practitioner. Training the Student Teacher, $115(2), 278-288$.

Yenice, N. (2012).Öğretmen adaylarının öz-yeterlik düzeyleri ile problem çözme becerilerinin incelenmesi. [Investigatıng the self-efficacy and problem solving skills of pre-service teachers]. Electronic Journal of Social Sciences, 11(39),36-58.

Yorulmaz, M. (2006). İlköğretim I. kademesinde görev yapan sınıf öğretmenlerinin yansıtıcı düşünmeye ilişkin görüş ve uygulamalarının değerlendirilmesi. Yayınlanmamış Yüksek Lisans Tezi. Frrat Üniversitesi Sosyal Bilimler Enstitüsü, Elazı̆̆.

Wenner, G. (2001). Science and mathematics efficacy beliefs held by practicing and prospective teachers: A 5-year perspective, Journal of Science Education and Technology, Vol. 10, No. 2,181187. 